\section{Caracterização de um antígeno de 13kDa (Sm13) do tegumento do Schistosomamansoni}

Sm13 é um antígeno de $13 \mathrm{kDa}$ reconhecido fortemente por soro de camundongos vacinados com preparações de membranas tegumentares de vermes adultos de Schistosoma mansoni. O ponto inicial para caracterização desse antígeno foi o isolamento prévio do gene codificando Sm13. Esse gene foi subclonado no vetor de expressão pMal-cri, de forma que Sm13 recombinante (rSm13) pudesse ser produzida em grande quantidade, em fusão com a "maltose binding protein" (MBP-rSm13). O produto recombinante foi utilizado na obtenção de anticorpos que permitiram vários estudos imunoquímicos e na avaliação da participação de Sm13 na resposta imune que se desenvolve na esquistossomose. Os anticorpos produzidos em coelhos foram capazes de reconhecer rSm13 e Sm13 nativa por "Western blot". Além disso as , análises dos "Western blot" forneceram evidências bioquímicas para a associação de Sm13 com membranas tegumentares: a)em experimentos com triton X-114, Sm13 particionou para a fase detergente; comportando-se como proteína integral de membrana; b) $\mathrm{Sm} 13$ foi detectada em membranas tegumentares purificadas. Outras evidências apontando para a localização tegumentar de Sm13 foram provenientes de estudos de secções de vermes adultos. No sentido de investigar a cinética de expressão de $\mathrm{Sm} 13$, experimentos adicionais com "Western blot" foram utilizados em diferentes estágios de desenvolvimento do $S$. mansoni; envolvendo desde miracídio até o estágio de verme adulto. Esses estudos mostraram que Sm13 está presente apenas em vermes hepáticos obtidos 2, 3, 4, 5 e 6 semanas após a infecção, sugerindo que o gene é regulado durante a maturação parasitária. Contudo, está presente igualmente em vermes adultos machos e fêmeas, indicando que sua regulação independe da diferenciação sexual. Em experimentos preliminares não foi demonstrado que MBP-

\section{Characterization of a 13kDa (Sm13) tegumental antigen of Schistosomamansoni}

Sm13 is a $13 \mathrm{kDa}$ antigen strongly recognized by serum from mice protectively vaccinated with adult worm tegumental membranes of Schistosoma mansoni. The gene for $\mathrm{Sm} 13$ was previously isolated allowing the molecular and immunological characterization of the antigen. In order to produce large amounts of purified recombinant Sm13 (rSm13)/ maltose binding protein fusion (MBP-rSm13), the gene was subcloned in the pMal-cri expression vector. The recombinant product was used do raise antibodies and evaluate the role of $\mathrm{Sm} 13$ in the immune response elicited by schistosomiasis. The antibodies raised in rabbits were able to recognize $\mathrm{rSm} 13$ and native $\mathrm{Sm} 13$ by Western blot. In addition, Western-blot analysis provided evidence for associating Sm13 to tegumental membranes: a) Sm13 partitioned to the detergent phase of Triton X-114, a behavior common to integral membrane proteins; b) Sm13 co-purifies with tegumental proteins. Further evidence pointing to the tegumental localization of Sm13 was provided by immunofluorescence studies using adult worm sections. Additional Westernblot analyses were carried out in different developmental stages of Schistosoma mansoni, ranging from miracidia to adult worms. These investigations detected Sm13 in 2-, 3-, 4-, 5- and 6 -week worms, suggesting that the gene is regulated during the parasite maturation. However, Sm13 is equally detected in male and female adult worms, indicating that the regulation is independent of sexual differentiation. Preliminary experiments were unsuccessfully undertaken to demonstrate a direct protective effect of MBPrSm13 in mice. However, MBP-rSm13 is recognized in ELISA and Western blot by serum from some schistosomiasis patients, indicating a role for $\mathrm{Sm} 13$ in the immune response elicited in human schistosomiasis. 
rSm13 protege camundongos contra infecções desafio com o S. mansoni. Entretanto, o reconhecimento de MBP-rSm13 por anticorpos de alguns pacientes esquistossomóticos, tanto em ELISA como em "Western blot" indica que Sm13 participa da resposta imune que se desenvolve na esquistossomose humana.

\section{Edeneide Maria Xavier}

Tese apresentada ao Centro de Ciências Biológicas da Universidade Federal de Pernambuco para otenção do Título de Mestre.

Recife, PE, Brasil, 1999. 